\title{
Distribution and quantitative patterns of mast cells in ovary and uterus of rat
}

\author{
Distribución y patrones cuantitativos de mastocitos en el ovario y útero de rata \\ T Karaca*, M Yörük, S Uslu \\ University of Yüzüncü Yil, Faculty of Veterinary Medicine, Department of Histology and Embryology, \\ Kampus, 65080, Van, Turkey
}

\begin{abstract}
RESUMEN
El objetivo de este estudio fue evaluar la distribución de mastocitos en el ovario y el útero durante el ciclo estral de ratas. Se utilizaron cuarenta ratas Albino de Wistar hembras, de 10 a 12 semanas de edad. Se tomaron muestras de los tejidos del ovario y útero para luego ser fijadas en Mota por 48 horas y parafina, luego se cortaron secciones de $6 \mu \mathrm{m}$ de espesor las cuales fueron teñidas con Azul de Toluidina (1\% de solución acuosa) y Alcian safranina-azul (pH: 1,0, utilizando $0,1 \mathrm{HCl}$ N como tampón). En el ovario, los mastocitos se presentaron principalmente en la túnica albugínea, en las áreas intersticiales entre folículos o cuerpos lúteos y en la proximidad de vasos sanguíneos en la médula. El número de mastocitos en la médula y la corteza ovárica y en el endometrio y miometrio uterino fueron mayores durante el estro, metaestro, las fases de estro y metaestro, respectivamente. Se encontró que el número de mastocitos fue mayor en la médula $(7,4 \pm 0,52)$ y la corteza ovárica $(2,1 \pm 0,30)$ de hembras en estro, en comparación a otras fases del ciclo estral $(\mathrm{P}<0,05)$, con un mayor número en el endometrio de hembras en estro y metaestro $(6,8 \pm 0,45$ para el estro, $6,2 \pm 0,56$ para el metaestro) y en el miometrio $(7,1 \pm 0,63$ para el estro, 7,5 $\pm 0,33$ para el metaestro) comparado a otras fases del ciclo $(\mathrm{P}<0,05)$. Durante todas las etapas del ciclo estral, excepto el proestro, los mastocitos teñidos con safranina se mostraron numerosos en todos los tejidos. Los mastocitos resultaron safranina positivos en el miometrio sólo en el proestro. Se concluyó que algunos cambios fisiológicos podrían ser responsables de la variación en la distribución de mastocitos en los tejidos ováricos y uterinos de la rata durante el ciclo estral.
\end{abstract}

Palabras clave: mastocitos, ciclo estral, rata

Key words: mast cells, oestrous cycle, rat.

\section{INTRODUCTION}

Mast cells, the major source of biogenic amines, namely histamine, originate from the bone marrow (Galli 1990). Mast cells are widely distributed throughout many different tissues and organs including the ovaries of mice, rats, hamsters and cows (Spaziani 1975, Jones et al 1980, Nakamura et al 1987, Krishna et al 1989, Aydin et al 1998). In species with a well-developed interstitial cortical stroma and a long oestrous cycle, as cow, mast cells reside both in the cortex and in the medulla of the ovary (Nakamura et al 1987). In species with a short oestrous cycle, as rat and hamster, mast cells are found only in the medulla (Jones et al. 1980, Krishna et al 1989).

During the oestrous cycle, the endometrium of all mammals undergoes proliferation and differentiation in response to changes in sex steroid hormone levels. Mast cells in the reproductive organs in mice could play an important role as concerns the regulation of blood flow

Aceptado: 31.10.2006

* Corresponding Author: Dr. Turan KARACA, University of Yüzüncü Yil, Faculty of Veterinary Medicine, Department of Histology and Embryology, Kampus, 65080, Van, Turkey. Telephone: +90 432 2251024, Fax: +90 432225 1127. e-mail: turankaraca74@hotmail.com, turan.karaca@gmail.com
(Spaziani 1975). Immunohistochemical, functional and histological investigations indicated that mast cells in human uterus differ from those in lung and skin (Massey et al 1991, Tainsh et al 1991). Mature mast cells contain granules that store preformed effector molecules such as histamine, serotonin, serine proteases, exopeptidases and neuropeptides (Stevens and Austen 1989). When activated, mast cells release these granules in a process referred to as compound exocytosis or degranulation (Dvorak 1991).

Many studies have reported the presence of mast cells in the mammalian uterus. Using staining of the mast cells with an acidic solution of toluidine blue, some authors have observed an increased quantity of mast cell during progesterone predominance and decreased number due to oestrogens (Maraspin and Bo 1971), while Mathur and Chaudhury (1988) have found no difference throughout the oestrous cycle. The aim of the present study was to establish the pattern of change in mast cell numbers in the uterus and ovary of Wistar Albino rats during the oestrous cycle.

\section{MATERIAL AND METHODS}

Female Wistar Albino rats 10-12 weeks old (250$300 \mathrm{~g}$ ) were used. Rats were given standard food pellets (Murat Animal Food Product Co., Ankara, Turkey) and 
drinking water ad libitum. All animals were housed in stainless steel cages under standard laboratory conditions (light $07: 00$ to $20: 00 \mathrm{~h}, 21 \pm 2{ }^{\circ} \mathrm{C}$, relative humidity $55 \%$ ), and received humane care according to the criteria outlined in the 'Guide for the Care and Use of Laboratory Animals' prepared by the National Academy of Sciences and published by the National Institute of Health. A total of 40 cycling female rats were used. In each female rat, stage of the oestrus cycle was determined by vaginal smear. After taking vaginal smears, rats were killed early in the morning for each day of the oestrus cycle. The uterus and both ovaries were dissected and fixed in Mota's fixative (Basic Lead Acetate (BLA); $1 \mathrm{~g}$ basic lead acetate, $50 \mathrm{ml}$ ethanol, $50 \mathrm{ml}$ distilled water, $0.5 \mathrm{ml}$ glacial acetic acid) at room temperature for $48 \mathrm{~h}$ and cross-sections were processed routinely for light microscopy by means of paraffin technique. Sections of $6 \mu \mathrm{m}$ thickness were stained with toluidine blue ( $1 \%$ aqueous solution) and Alcian blue-safranin (0.9 g Alcian blue, $0.045 \mathrm{~g}$ safranin, $1.2 \mathrm{~g}$ ferric ammonium sulphate; $\mathrm{pH}$ : 1.0, buffered by using $0.1 \mathrm{~N} \mathrm{HCl}$ ) for evaluation of mast cell distribution. Mast cells were identified by the characteristic metachromatic staining of secretory granules by toluidine blue. Toluidine blue stain was used to demonstrate degree of degranulation of mast cells. The degree of sulphation of the matrix of mast cells was estimated using Alcian blue and safranin staining in sections (Gaytan et al 1990). Tissue sections were examined under light microscopy (x200) and the number of mast cells counted in random high-power fields using a Nikon Optiphot 2 light microscope incorporating a square graticule in the eyepiece. Ten serial sections were examined by light microscopy on the preparations of each animal, which were previously screened and standardized. Mast cells (MC) were counted and the arithmetic mean was calculated (eyepiece x10, objective x20, a total side length of $0.225 \mathrm{~mm}$ ). The MC density in each site was calculated and recorded as MC numbers $/ \mathrm{mm}^{2}$.

Statistical analysis. The data were expressed as the mean \pm standard deviation (SE). Bartlett test was used in order to determine whether the data were heterogeneous or homogeneous. Then Bonferroni multiple comparison procedure was utilized for identifying differences among means. Differences were considered significant at $\mathrm{P}<0.01$.

\section{RESULTS}

Mast cells with strong metachromatically stained were observed in the ovary and uterus during sexual cycle. Degranulated mast cells were only occasionally found. The mast cells were ovoid but they were spindle in the collagenous stroma (figure 1). Regardless of oestrous cycle phase, the mast cells were found in the cellular stroma of the albuginea and in interstitium among fol- licles and corpora lutea. In the ovarian medulla, mast cells were clearly associated with the vasculature, both of the blood and lymphatic vessels. The lowest mast cell numbers were found in the proestrous phase, and increased at oestrus, metaoestrous and dioestrous in both the ovary and uterus (figure 2). The number of mast cells in the ovarian cortex was highest in the metaoestrous phase. During the oestrous cycle, significantly higher mast cell counts were observed at oestrous and metaoestrous $(\mathrm{P}<0.05)$ compared to other stages of the cycle (table 1$)$.

Mast cells were also present in the uterus (figure 3). Endometrial mast cells were normally seen in the stroma close to epithelial cells in endometrium but they were absent in the epithelium. In the myometrium they were found inside and between muscle bundles and around the blood vessels. During all stages of the oestrous cycle except for the proestrous, in Alcian blue and safranin staining method, granulated and safranin positive mast cells were abundant in all tissues (figures 4,5 ). The results of mast cell counts are summarized in table 1 .

\section{DISCUSSION}

The present study was carried out to determine the morphological distribution of mast cell numbers in uterus and ovary during oestrous cycle. We were able to demonstrate that mast cell density in different tissue and region locations within both the ovary and uterus varies between different oestrous phases. Jones et al (1980) showed that the number of mast cells in rat ovarian medulla was highest at oestrus and lowest at proestrous, while mast cells also degranulated at proestrous. In the hamster ovary, the lowest mast cell numbers and increased degranulation and histamine level were reported at proestrous by Krishna and Terranova (1991).

Cyclical changes in mast cell numbers have been observed throughout the human menstrual cycle (Drudy et al 1990), and it has been suggested that mast cells are specifically sensitive to changes in hormonal levels (Brandon and Evans 1983, Krishna and Terranova 1985). In the human, mast cell numbers in the postmenopausal uterus are significantly lower than in the endometrium during the reproductive years (Drudy et al 1991). In the present study, significant changes in the number of mast cells relating to the oestrous cycle were observed. These results showed similarity with previous studies.

In the present study, mast cells were not observed on the inside of the follicles, but were present in high densities in the medulla and the interstitial cortical stroma throughout the oestrous cycle. Nakamura et al (1987) counted these cells in the theca externa of dominant follicles and in the capsule of the corpora lutea of the bovine ovary and did not observe mast cells in the interstitial cortical stroma. A similar result was reported in the human ovary (Balboni 1976). Another study reported that mast cells were absent in the ovary of hamster (Krishna 


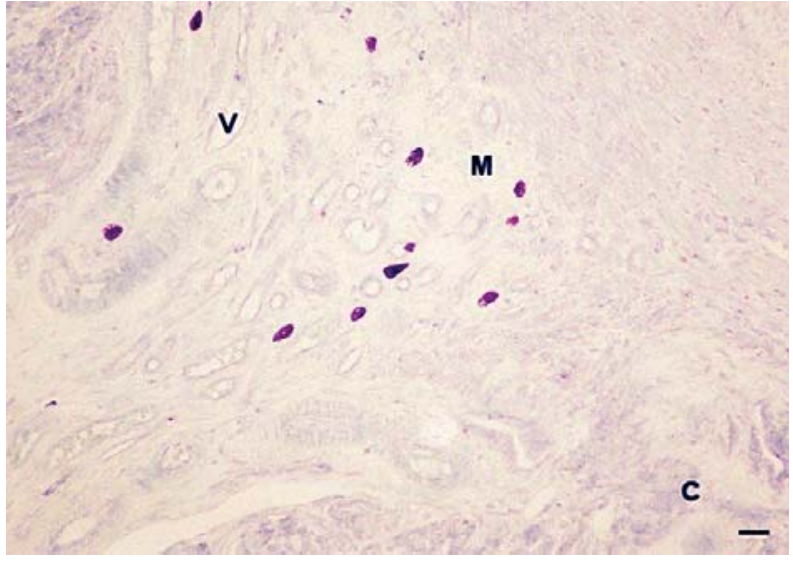

Figure 1. Mast cells in the medulla of ovary during the dioestrous phase. M: Medulla, V: Vessel, C: Cortex. Toluidine Blue $($ Bar $=60 \mu \mathrm{m})$.

Mastocitos en el ovario durante la fase de diestro. M: Médula, V: Vaso, C: Corteza. Azul de Toluidina (Barra $=60 \mu \mathrm{m})$

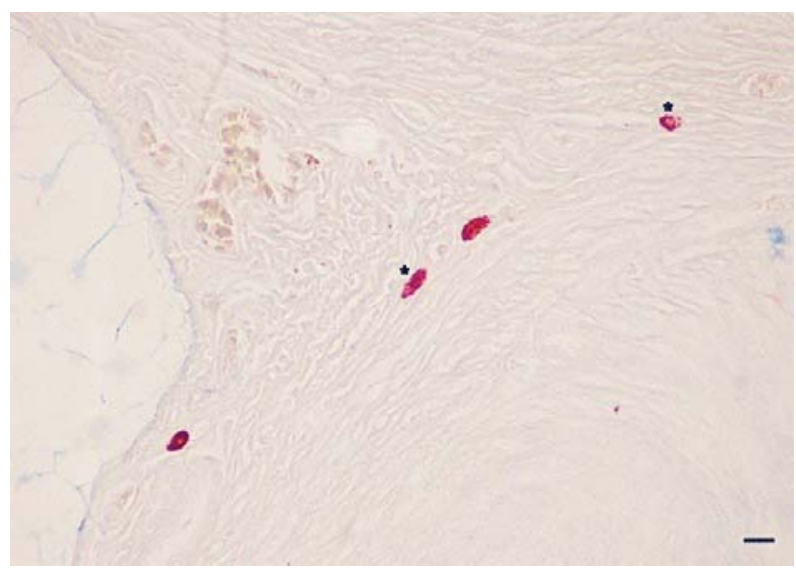

Figure 3. Mast cells in the uterus during the dioestrous phase. *: Mast cells, Toluidine Blue $(\mathrm{Bar}=60 \mu \mathrm{m})$.

Mastocitos en el útero durante la fase de diestro. *: Mastocitos. Azul de Toluidina (Barra $=60 \mu \mathrm{m}$ ).

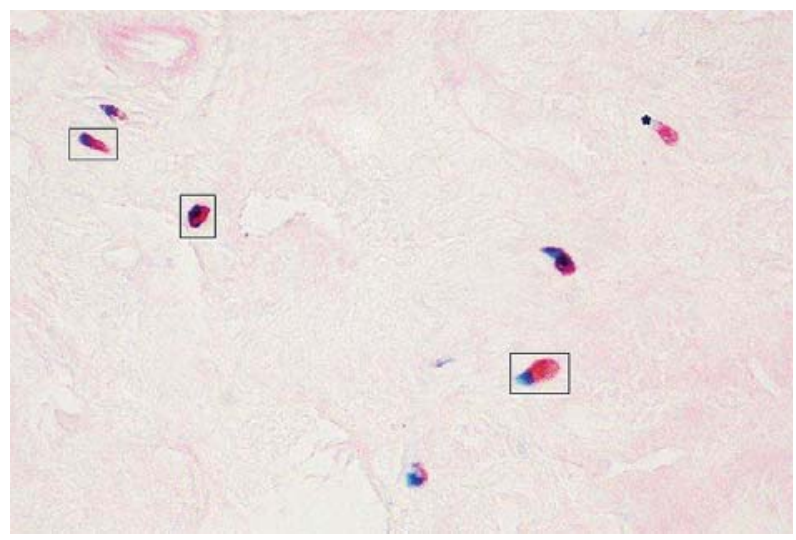

Figure 5. Red-stained (*) and mix-stained (windows) mast cells in the ovary during the metaoestrous phase. Alcian bluesafranin $($ Bar $=30 \mu \mathrm{m})$.

Mastocitos teñidos de rojo (*) y bicolores (ventanas) en el ovario durante la fase de metaestro. Alcian safranina azul (Barra = $30 \mu \mathrm{m})$.

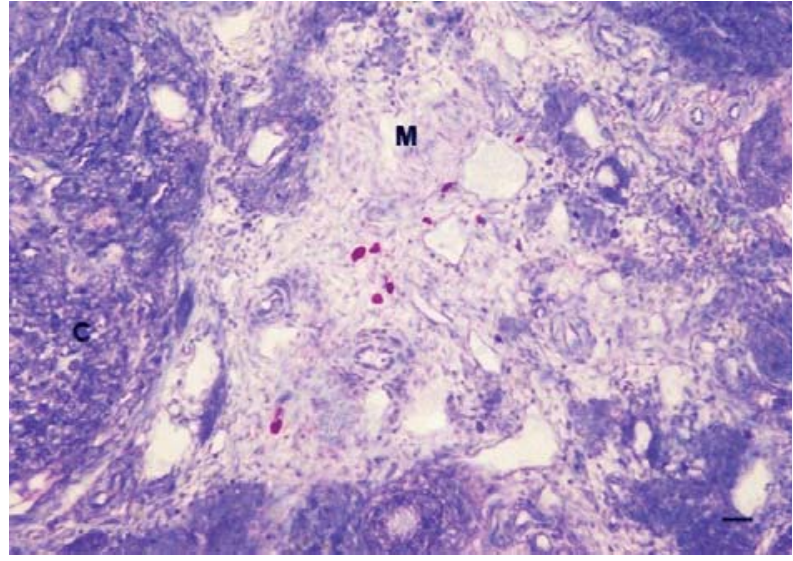

Figure 2. Mast cells in the ovary during the metaoestrous phase. M: Medulla, C: Cortex. Toluidine Blue $(\mathrm{Bar}=60 \mu \mathrm{m})$.

Mastocitos en el ovario durante la fase de metaestro. M: Médula, C: Corteza. Azul de Toluidina (Barra = $60 \mu \mathrm{m})$

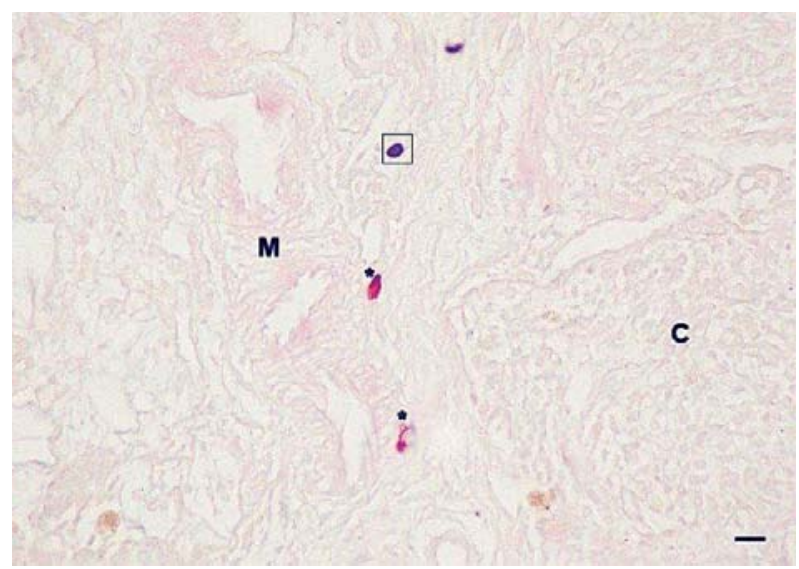

Figure 4. Red-stained (*) and blue-stained (window) mast cells in the ovary during the oestrous phase. M: Medulla, C: Cortex. Alcian blue-safranin $(\mathrm{Bar}=30 \mu \mathrm{m})$.

Mastocitos teñidos en rojo (*) y azul (ventana) en el ovario durante la fase de estro. M: Médula, C: Corteza. Alcian safranina $\operatorname{azul}($ Barra $=30 \mu \mathrm{m})$.

and Terranova 1985), whereas in the cow they were present in the thecal tissues and in the capsule of the corpus luteum (Nakamura et al 1987). Parshad and Kahpalia (1988) observed mast cells in the atresic follicles of the immature rat ovary. These cells are possibly related to the process of atresia, as they were not observed in the normal follicles. Aydin et al (1998) and Jones et al (1980) did not describe mast cells in the cortex at proestrous. However, Gaytan et al (1991) described mast cells in the cortex of the ovary.

The mechanisms underlying cyclical changes in ovarian mast cells are not clear. Changes in the mast cells could be due to degranulation-regranulation patterns, cell death or cell migration (Gaytan et al 1991). The function of intra-ovarian mast cells requires clarification. At 
Table 1. Mast cell counts during the rat oestrous cycle after staining with Toluidine Blue.

Recuento de mastocitos durante el ciclo estral de la rata después de teñir con Azul de Toluidina.

\begin{tabular}{lccccc}
\hline & \multicolumn{2}{c}{ Ovary } & & \multicolumn{2}{c}{ Uterus } \\
\cline { 2 - 3 } \cline { 5 - 6 } Oestrous Phase & Medulla & Cortex & & Endometrium & Myometrium \\
\hline Proestrous & $1.8 \pm 0.32^{\mathrm{c}}$ & $0.6 \pm 0.09^{\mathrm{d}}$ & & $2.1 \pm 0.45^{\mathrm{c}}$ & $3.5 \pm 0.15^{\mathrm{c}}$ \\
Oestrous & $7.4 \pm 0.59^{\mathrm{a}}$ & $2.1 \pm 0.30^{\mathrm{c}}$ & & $6.8 \pm 0.45^{\mathrm{a}}$ & $7.1 \pm 0.63^{\mathrm{a}}$ \\
Metaoestrous & $5.6 \pm 0.84^{\mathrm{b}}$ & $7.8 \pm 1.0^{\mathrm{a}}$ & & $6.2 \pm 0.11^{\mathrm{a}}$ & $7.5 \pm 0.33^{\mathrm{a}}$ \\
Dioestrous & $5.2 \pm 0.75^{\mathrm{b}}$ & $4.6 \pm 0.30^{\mathrm{b}}$ & & $5.4 \pm 0.84^{\mathrm{b}}$ & $5.7 \pm 0.84^{\mathrm{b}}$ \\
\hline
\end{tabular}

Values are Mean \pm S.E., $n=10$ for each phase.

Means followed by same letters in a column are not significantly different at $5 \%$ level of significance.

present, they are considered to be involved in the increased vascular permeability after degranulation and histamine release during the preovulatory period (Jones et al 1980, Krishna et al 1989).

In connective tissue, mast cells red-stained granules by Alcian blue-safranin have been related to the presence of highly $N$-sulphated glycosaminoglycans such as heparin (Pearce 1986). In addition to heparin, connective tissue mast cells have high histamine content and these cells are stained by either Alcian blue or safranin (Galli 1990). When the cells increase their heparin content, they stain with safranin (red-stained granules) and when they decrease it, they stain only with Alcian blue (blue-stained granules). Thus, histamine content may be increased in mast cells staining blue with Alcian blue. In the present study, mast cell density in the mucosal was notably greater than connective tissue mast cell density in the ovary and uterus. This is similar to the findings of Aydin et al (1998).

In mammals, histamine exists in a bound form in granules of tissue mast cells, as well as in circulating basophiles and blood platelets (Siraganian 1983). Vasodilatation, oedema and uterine growth observed in oestrous have been attributed to oestrogen-induced release of histamine from uterine mast cells (Spaziani 1975), which could indicate that in uterine tissue mast cells could be important repositories of histamine. Many studies have reported the presence of mast cells in the mammalian uterus (Brandon and Evans 1983, Drudy et al 1990 and 1991, Jones et al 1980). Besides that, some investigators have also observed an increase in mast cell numbers during progesterone predominance and a decline due to the action of oestrogens (Maraspin and Bo 1971), although others have found no difference throughout the oestrous cycle (Mathur and Chaudhury 1988).

In the present study, differences in numbers of mast cells were observed in different parts of the uterus and during cyclical changes at the same sites. The endometrium contained fewer and smaller mast cells than the myometrium. In the endometrium, mast cells were observed most in the oestrous phase, whereas they were observed least in dioestrous and proestrous phases. This is similar to the findings of Crow et al (1991). It has been suggested that mast cells in animals are specifically sensitive to changes in hormonal levels (Brandon and Evans 1983, Krishna and Terranova 1985).

It was concluded that distribution of mast cells can vary depending on some physiological alterations during the oestrus cycle in rat ovarian and uterine tissues. However, the specific role of mast cells and their direct actions on reproductive processes in ovary and uterus tissues remain to be determined.

\section{SUMMARY}

The aim of this study was to evaluate the distribution of mast cells in the ovary and uterus of rats during their oestrous cycle. Fourty female Wistar Albino rats, 10-12 weeks old, were used. Ovary and uterus tissues were fixed in Mota's fixative for $48 \mathrm{~h}$ and embedded in paraffin. Sections of $6 \mu \mathrm{m}$ thickness were cut and stained with toluidine blue (1\% aqueous solution) and Alcian blue-safranin (pH: 1.0, buffered by using $0.1 \mathrm{~N} \mathrm{HCl}$ ). In the ovary, the mast cells were mainly present in the tunica albuginea, in the interstitial areas between follicles or corpora lutea and in the vicinity of blood vessels in the medulla. The number of mast cells in the ovarian medulla and cortex and the uterine endometrium and myometrium were highest in the oestrous, metaoestrous, oestrous and metaoestrous phases, respectively. The number of mast cells was higher in the ovarian medulla $(7.4 \pm 0.52)$ and cortex $(2.1 \pm 0.30)$ during oestrus rather than in other phases of the oestrous cycle $(\mathrm{P}<0.05)$, with the highest number in the endometrium during the oestrous $(6.8 \pm 0.45)$ and metaoestrous $(6.2 \pm 0.56)$ and in the myometrium $(7.1 \pm 0.63$ for oestrous, $7.5 \pm 0.33$ for metaoestrous) of uterus compared to other phases of the cycle $(\mathrm{P}<0.05)$. Safranin-stained mast cells were numerous in all tissues during all stages of the oestrous cycle except the proestrous. Mast cells were safranin positive in the myometrium only during proestrous. It was concluded that some physiological changes could be responsible for the variation in the distribution of mast cells in the ovarian and uterine tissues of the rat during the oestrus cycle. 


\section{REFERENCES}

Aydin Y, N Tunçel, F Gürer, M Tunçel, M Kosar, G Oflaz. 1998 Ovarian, uterine and brain mast cells in female rats: Cyclic changes and contribution to tissue histamine. Comp Biochem Physiol Part A 120, 255-262.

Balboni GC. 1976. Histology of the ovary. In: James VHJ, Sergio M, Ginsti G (Eds) The Endocrine Function of the Human Ovary. London: Academic Press. Pp 1-24.

Brandon JM, JE Evans 1983. Changes in uterine mast cells during the estrous cycle in the Syrian hamster. Am J Anat 167, 241-247.

Crow J, M Wilkins, S Howe, L More, P Helliwell. 1991. Mast cells in the human genital tract. Int J Gynecol Pathol 10, 230-237.

Drudy L, BL Sheppard, J Bonnar. 1991. The mast cells and histamine concentration of the post-menopausal uterus. Eur J Obstet Gynecol Reprod Boil 42, 39-42.

Drudy L, BL Sheppard, J Bonnar. 1990. Mast cells in the normal uterus and dysfunctional uterine bleeding. Eur J Obstet Gynecol Reprod Biol 39, 193-201.

Dvorak AM. 1991. Basophil and mast cell degranulation and recovery. In: Harris JR, editor. Blood Cell Biochemistry. Vol 4, New York: Plenum Press. Pp 27-65.

Galli S J. 1990. New insights into 'The riddle of the mast cells': Microenvironmental regulation of mast cell development and phenotypic heterogeneity. Lab Invest 62, 5-33.

Gaytan F, J Aceitero, C Bellido, JE Sanchez-Criato, E Aguilar 1991. Estrus cycle-related changes in mast cell numbers in several ovarian compartments in the rat. Biol Reprod 45, 27-33.

Gaytan F, C Bellido, G Carrera, E Aguilar. 1990. Differentiation of mast cells during postnatal development of neonatally estrogen treated rats. Cell Tissue Res 259, 25-31.

Jones RE, D Duvall, LJ Guilette. 1980. Rat ovarian mast cells; distribution and cyclic changes. Anat Rec 197, 489-493.

Krishna A, K Beesley, PF Terranova. 1989. Histamine, mast cells and ovarian function. J Endocrinol 120,363-371.
Krishna A, PF Terranova. 1991. Compartmentalized mast cell degranulations in the ovarium hilum, fat pad, bursa and blood vessel regions of the cyclic hamster: Relationships to ovarian histamine and blood flow. Acta Anat 141, 18-25.

Krishna A, PF Terranova. 1985. Alterations in mast cell degranulation and ovarian histamine in the prooestrous hamster. Biol Reprod 32, 1211-1217.

Maraspin LE, WJ Bo. 1971. Effects of hormones, pregnancy and pseudopregnancy on the mast cell count in the rat uterus. Life Sci 10, 111-120.

Massey WA, C Guo, AM Dvorak, WC Hubbard, BS Bhagavan, VL Cohan, JA Warner, A Kagey-Sobotka, LM Lichtenstein. 1991. Human uterine mast cells - isolation, purification, characterization, ultrastructure and pharmacology. J Immunol 147, 1621-1627.

Mathur VS, RR Chaudhury. 1988. The effect of an intrauterine plastic device on the mast cell count in the rat uterus. J Reprod Fert 15, 135-138.

Nakamura Y, M Smith, A Krishna, P F Terranova. 1987. Increased number of mast cells in the dominant follicle of the cow: relationship among luteal stromal and hilar region. Biol Reprod 37, 546-549.

Parshad RK, K Kathpalia. 1988. Distribution and characteristics of mast cells in immature rat ovary. Indian J Exp Biol 26, 937-940.

Pearce FL. 1986. On the heterogeneity of mast cells. Pharmacology $32,61-71$.

Siraganian RP. 1983. Histamine secretion from mast cells and basophile. Trends Pharmacol Sci 10, 432-436.

Spaziani E. 1975. Accessory reproductive organs in mammals: Control of cell and tissue transport by sex hormones. Pharmacol Rev 27, 207-286

Stevens RL, KF Austen. 1989. Recent advances in the cellular and molecular biology of mast cells. Immunol Today 10, 381-386.

Tainsh KR, HYA Lau, WL Liu, FL Pearce. 1991. The human skin mast cell: a comparison with the human lung cell and a novel mast cell type, the uterine mast cell. Agents Actions 33, 16-19. 